\title{
Working Capital Management and Performance of Industrial and Consumer Goods Firms in Nigeria: A Comparative Analysis
}

\author{
Olaoye, Clement Olatunji, Adeboboye, Roseline \\ Department of Accounting, Ekiti State University, Ado-Ekiti Ekiti State, Nigeria \\ osaboboye@gmail.com
}

\begin{abstract}
This study conducted a comparative analysis on working capital management and performance of industrial and consumer goods firms in Nigeria. Precisely, the study compared effect of average collection period and average payment period on return on capital employed of selected industrial goods and consumer goods firms. 20 firms were randomly selected over a period of 10 years data were collected from annual report of the firms. This study used static data analyses to analyze data. Result showed average collection period and average payment period exert insignificant positive effect on return on capital employed of industrial goods firms, while both average collection period and average payment period exert insignificant negative effect on return on capital employed of consumer goods firms. Independent t-test result showed significant mean difference between coefficient estimate corresponding to industrial and consumer goods firms. This study concluded that there exists significant difference between the effect of working capital management on performance of industrial goods firms and consumer goods firms when performance is measured in terms of return on capital employed. Hence firms in both sub-sectors should be strategic when managing working capital, by setting higher average payment period in a manner that will not crowd-out their credit worthiness.
\end{abstract}

Keywords: Working Capital Management, Firm's Performance, Comparative Analysis.

\section{Introduction}

In business, especially manufacturing sector, effective working capital management is a means of enhancing performance, in order to gain competitive advantage in the manufacturing sector. Performance is the ability of a firm to use its assets to improve competitiveness (Iswatia, 2007). Effective and efficient working capital management is needed to achieve performance. In Nigeria, there are many shareholders who have invested heavily in manufacturing firms; due to the emergence of market that have been created domestically and internationally for manufactured products as pointed out by the activities in the stock market. Ogundipe, Idowu \& Ogundipe (2012) opined that, an improper management of working capital components that is account payables, account receivables and inventories will affect firm's operation. As witnessed in Nigeria, many manufacturing firms are shutting down among other factors, owing to poor working capital management. Few examples of such manufacturing firms are, Kastina steel, Aba textile mill Ltd, Golden guinea breweries Umuahia and Ajaokuta steel complex which reduced its staff from 5000 to 1000 in year 2008 (Jegede, 2017). This study was motivated by the evident problems of improper management of working capital components and the need for improve performance of the manufacturing sector in Nigeria, in the face of economy challenges as pointed out by Jegede (2017), the performance of the manufacturing sector.

In Nigeria, has not been significant due to improper management of working capital. According to Oladunjoye (2011), the performance of the manufacturing sector in Nigeria has been grounded among other things due to inadequate management of resources. Visibly, most previous studies in examination of working capital management and performance of quoted manufacturing firms, did not take into cognizance the uniqueness across sub-sectors of manufacturing sector (heterogeneity effects); this means that, previous studies treated firms across sub-sectors of the manufacturing sector as the same, with no consideration of the possible heterogeneity effects based on differences in operation and contribution of each sub-sector to the manufacturing output as a whole, examples of previous studies are; Ajayi, Abogun \& Odediran, 2017; Madugba \& Ogbonnaya, 2016; Eya, 2016; Akindele \& Odusina, 2015; Osundina, 2014; Angahar \& Alematu, 2014; Ojeani, 2014. Hence, this study conducted a comparative analysis, to compare the effect of working capital management on performance of industrial goods sub-sector with that of consumer goods sub-sector of the Nigerian manufacturing sector. Objectively, this study analyzed and compared the effect of average collection period and average payment period on return on capital employed of industrial goods sub-sector with that of consumer goods sub-sector of the manufacturing sector in Nigeria. 


\section{Literature Review}

Working Capital Management: Working capital management involves planning and controlling current assets and current liabilities in a manner that eliminates the risk of inability to meet short term obligation on one hand and avoid excessive investment in these assets, on the other hands (Elejelly, 2004). Lamberson (1995) opined that working capital management has become one of the most important issues in organization where many financial managers find it difficult to identify the important drivers of working capital and the maximum level of working capital. Firms can maximize risk and enhance financial performance where there is thorough understanding of the importance and drivers of working capital. The objective of working capital management is to achieve desired tradeoff between liquidity and profitability (Raheeman \& Nasr, 2007). To buttress the importance and drivers of working capital, Howorth \& Westhead (2003); Deloof (2003); Afza and Nazir (2007), stated that; efficient management of working capital is an important strategy which aims at increasing the market value of a firm. To increase market value of a firm management of firms will use the combinations of working capital policies and working strategies for working capital management. Uyar (2009) stated that, working capital policy is the key policy area which relate to the level of investment in working capital for a given level of operation and the extent to which working capital is financed from short-term funds such as a bank overdraft. A company should have working capital policies on the management of inventory, trade receivables, cash and short-term investments in order to minimize the possibility of illiquidity and inefficiency (Chittenden, Poutziouris \& Micheal, 1998). Mathur (2003) opined that working capital policy can broadly be divided into three categories as: Conservatives policy, Aggressive policy and Moderate policy.

The Conservative policy is used when a firm prefers to hold rather heavy cash and bank balance in current account or investments in readily marketable securities and as such having higher stock of raw materials and finished goods, so as to reduce the risks of out of stock and loss of sales while the aggressive know as restrictive working capital policy is used when a firm choose to operate with lower levels of inventory trade receivables and cash for a given level of activity or sales (Chittenden et al., 1998). It may result in disproportional losses because of the risk of stock out and subsequently loss of production as well as losing sales which can negatively have effect on the financial performance (Profitability) of the firm. Under the Moderate policy, the firm tends to tread a middle path between the aggressive and conservative approaches of working capital policy. That is the level of working capital will be moderate neither too high nor too low but just proportionately. However, a firm can choose to employ both policies in order to maintain a satisfactory level of working capital (Charitou, Lois \& Christoforou, 2016). According to Chittenden et al. (1998), the working capital policies of a company can be characterized as aggressive, moderate or conservative only by comparing them with the working capital policies of similar companies. Working Capital Management policy deals with the first decision of "how much to invest in current assets to achieve the targeted Revenue" while working capital management strategies or approaches deal with the second decision of how should current asset investment be financed, that is, the mix of long- and short-term finance. Also working capital strategies are divided into Aggressive Conservative and Hedging (Maturity Matching). Effective working capital management is vital to the stability and survival of a business, just as the human heart is vital to the life of any human being. Effective working capital management forms a crucial basis for well performing and growth-oriented firms (Jagongo \& Makori, 2013; Knauer \& Wohrman, 2013).

Account Receivables Management: According to Aminu \& Zainudin (2015), receivables represent unpaid credit extended to customer by the business. That is, account receivables are customers who have not yet made payments for goods or services which a firm has provided. Account receivables are also called debtors arise from sales on credit (Van Hore, 2001). Since the purposes of offering credit are to maximize profitability, the cost of debt collection should not be allowed to exceed the amount recovered. Therefore, account receivable management constitutes the management of firm's debtors. Firms should put in place policies that will afford them the ability to monitor their receivables. Firms that are not diligent in managing their credit operations can suffer large losses from bad debt, especially during recession, when customers may have trouble paying their bills (Moles, Parriso \& Kidwell, 2011). For account receivables to be effectively managed, credit policy and collection period play very vital roles, since this credit policy and collection period largely influence the management of account receivable. Moles et al. (2011), advice that, it is very important for firms to consider the credit rating of a customer before granting credit to avoid bad debts. 
Shim \& Siegel (2000) pointed out that, accounts receivable management includes selecting the good customers and speeding up the collections from such customers. Efforts should be made by firms to put proper measures in place that will enable them go after late payers and also have a regular trade receivables analysis. Van Hore \& Wachowicz (2004) stated that, some thoughts could also be given to charging interest on overdue accounts to encourage timely payment depending on the likely response by customer to reduce the risk of bad debt it is imperatives for firms to carefully assess the credit worthiness of new customers before credit is granted to them. Also, a firm needs to review on regular interval the credit worthiness of existing customers. Firms need to have necessary information about the company it is to have business dealing with, so as to make informed decision and judgement (Padachi, 2006). The necessary information a firm need, can be gotten from variety of sources such as asking new customers to provide bank references to confirm their financial standings and trade reference to indicate satisfactory conduct of business affairs. Other sources could be audited accounts and report of prospective customers, past experience with similar companies can serve as a useful basis of making decision etc. Furthermore, Brealey, Myers \& Allen (2006), described account receivables management to involve the following steps: first firms should decide the sales terms on which firms sell their goods to their customers, secondly firms should make decision on what evidence a firm requires from their customers who owes the payments, thirdly firms should analyze the risky customers and non-risky customers who are likely to pay their bills, this is termed trade receivables analysis. Fourth, firms should draw up the credit policy that will show to what extent the firms will allow their customers to pay their bills on credit terms. Fifth, firms should design a collection policy that will enable those makes sales on credit and advert, the problems of collecting the payment when the bills become due.

Account Payables Management: This is one of the major sources of secured short term financing (Gitman, 2009). It is the major single class of short-term debt. Account payables are said to arise as a result of when firms purchase on credit and the debt is recorded as Account payable. This is to say that account payables are suppliers whose invoice for goods or services have been processed but have not yet been paid. Most organization often regard the amount owes to creditors as a source of free credit, it is free when firms make payment within the discount period, while it is said to be costly when firms forego available discounts and decide to make payment after the due date thereby incurring substantial additional costs. Utilizing the value of relationship with payee is a sound objective that should be highlighted as important as having the optional level of prevention. This is to say that a sound healthy relationship between firms and their supplier should be regarded as very important as trying to prevent excessive and unwanted debt. According to Singh (2004), the liquidity of position firms mainly depends upon, accounts receivable collection and payable deferred policing as well as inventories conversion period of firms. As such, trade credit is used as a marketing tool to facilitate the selling process and to compete in the market. Also credit terms are integral part of firms pricing policy, placing credit terms favorably, such as lengthening a credit period or increasing a cash discount is equivalent to a price cut, thus enabling the firm to evade price restrictions, and this subtle technique, also provides the seller a more flexible approach to pricing without fear of competitor retaliation (Schwartz, 1994; Cheng Pike, 2003).

Firms are advised to strike a balance when trying to main maximum cash flow by delaying payments as long as it is reasonably possible and when trying to create and maintain positive credit ratings as well as good relationships with supplies and creditors. Although credit is a vital part of effective cash positioning and purchasing initiate cash outflows but overzealous purchasing function can create liquidity problems (Duru \& Okpe, 2016). That is why account payable should be seen at all times as debts that must be paid off within a given period to avoid default. Uyar (2009) stated that, account or trade payables deferral period is the average time taken by a company to pay its trade payable (supplies). This trade payables deferral period is computed by dividing account payables by net purchases multiplies by 365 days (Raheeman \& Nasr, 2007). The number of days account payables, reflect the average time it takes firms to pay their supplies, the higher the number; the longer firms take to settle their payment commitments to their suppliers. The average payables period is used as a proxy for account payables period which is a partial component of the cash conversion cycle and this cycle is used to measure the efficiency of working capital management (Brigham \& Ehrhardt, 2004). While the account payables turnover ratio is a short-term liquidity measure used to quantify the rate at which a company pays off its suppliers. It is calculated by taking the total purchase made from suppliers or cost of sales and dividing it by the average account payables amount during the same period. This measure shows investors how many times per period the company pays it average payables amount. 
The account payables are listed under a company current liability on its balance sheet. Note that if the account payables turnover ratio is falling from one period to another this is a sign that the firm is taking longer to pay off its suppliers than it was in previous time periods, but if is increasing from one period to another it means that the firms paying off suppliers at a faster rate. So the effective management lies on whether the firm is enjoying the actual credit period offered by the suppliers and how positively it has impacted the firm's liquidity position/financial performance.

Industrial Goods Sub-Sector: Industrial goods sub-sector is a sub-sector of manufacturing sector that is responsible for the production of raw materials, equipment, or product components (industrial goods) required by businesses for the production or distribution of goods or other services (Chete, Adeoti, Adeyinka \& Ogundele, 2016). Currently in Nigeria, the industrial goods sub-sector has seventeen companies as listed in the Nigeria stock exchange. According to Central Bank of Nigeria economic report (2000), before independence in 1960, the Nigerian economy was mainly agrarian both in production for domestic consumption and exports. But post-independence, after the discovery of oil and its exploration and exportation in commercial quantities, the fortunes of agriculture gradually diminished and industrialization sprang up. Based on Central Bank of Nigeria Purchaser's manager's Index report (PMI) 2017, firms in the industrial goods sub-sector contributed to the growth of the manufacturing sector, which in turn led to the expansion of the Nigerian economy. Based on Central Bank of Nigeria PMI report, one can assert that, firms of the industrial goods sub-sector have an effective management of their working capital components due to their contributions to the economy.

Consumer Goods Sub-Sector: Consumer goods sub-sector is the sector that deals with the finished products that are available for public consumption (Aluko, 2018). This implies that, this sub-sector deal primarily with the process of manufacturing goods for consumption by end users. It is also regarded as a sub-sector which creates goods that are consumed rather than goods that are used for production. Based on Central bank of Nigeria PMI report, firms of the consumer goods sub-sector, contributes positively to economic growth in Nigeria. Adebayo (2016) stated that, the consumer goods sub-sector in Nigeria is home to many giant multinational companies and host to domestic companies who serve its over 170 million people. Consumer goods sub-sector remains one of the most attractive sub-sectors of the manufacturing sector because of the number of people it serves and its contribution to the economy, this implies that; firms of the consumer goods sub-sector also have an effective management of their working capital components due to their contribution to the economy.

Empirical Review: Niresh (2012) examined working capital management and financial performance of manufacturing sector in Sri Lanka. Where return on asset and return on equity were used as proxies for financial performance. The study employed correlation and regression analysis models for analyzing data and result of the analysis revealed that, there is no significant relationship between cash conversion cycle and performance measures and hence the study concluded that manufacturing firms in Sri Lanka should follow conservative working capital management policy. Caballero, Teruel, \& Solano (2014), conducted a study on working capital management, corporate performance and financial constraints in United State of America. The purpose was to examine the relationship between working capital management and corporate performance. The researchers used financial ratios and simple linear regression analysis to analyze data and the result showed that, there is a high statistically significant U-shaped inverted relationship between firm's performance and working capital management.

The researchers concluded that, when a firm has an ideal level of investment in its working capital then it will balance expenses and benefits which ultimately maximize the firm's performance. Naeem, Malik, Muhammed \& Mehbood (2014), examined the effect of working capital management on firm's performance. The purpose of the study was to investigate whether, working capital management affect the performance of non-financial firms listed on Pakistan stock exchange. Panel data model was used to analyze data. The researchers used three variables to proxy performance, they are; gross profit margin, return on asset and return on equity. While average inventory period, average collection period and average payment period, where the working capital variables tested. The study revealed that, working capital management statistically insignificantly has effect on firm's performance. Osundina (2014) conducted a study on the relationship between working capital management and profitability of quoted food and beverages manufacturing firms in Nigeria. 
Operating profit was used to measure profitability. The researcher made use of primary data through survey research and regression analysis (OLS) was used to establish the relationship between profitability and working capital components. The result revealed that, working capital management has significant positive relationship with profitability. Salman, Oyetayo \& Oriowo (2014), conducted a study on working capital management and profitability of selected listed manufacturing companies in Nigeria. Data were sourced from audited financial statements of the firms selected. Data were analyzed using Pearson correlation coefficient and multiple regression analysis, while ordinary least square (OLS) was used for estimation. The result revealed that, working capital has significant negative effect on return on assets (ROA) and return on equity (ROE). The researchers concluded that, firm's performance can be increased with short size of cash conversion cycle. Akindele \& Odusina (2015) examined the relationship between working capital management and firm's profitability of quoted companies in Nigeria. Data were sourced from audited financial statements of the companies. Data collected were analyzed using multiple regression analysis and the result revealed that, there is a negative relationship between working capital component (cash conversion cycle) and firm profitability that was proxy by return on asset (ROA). Mun \& Jang (2015) examined working capital management and profitability of United State of America restaurants. The researchers employed simple linear regression analysis to analyze data collected and the findings revealed a significant inverted U-shape relationship between working capital.

Management and a firm's profitability (Return on Assets) and this indicated the existence of an optimal working capital management level for United State of America restaurants. The researchers concluded that a firm's cash level is an essential element for an efficient working capital management. Eya (2016) examined the effect of working capital management on performance of food and beverages industries in Nigeria, using Nestle Food Nigeria plc as a case study. The researcher made use of Ordinary Least Squares (OLS) estimation and regression analysis, to analyze data used in the study. The significant of the study was to show how companies manage their working capital. The findings revealed that, working capital management have a positive effect on performance. The researcher concluded that, the management of working capital is important to business organization performance and among other variables management of Nestle Food Nigeria plc should pay more attention to the quick ratio as its management indicates the best way of measuring the amount of the most liquid current assets. Haruna (2016) conducted a study on the effect of working capital management on performance of small and medium enterprises in Nigeria. The significant of the study was to show the need to properly manage the available financial resources. The researcher made use of regression models to analyze data. The findings revealed that, working capital management have positive effect on performance of Small and Medium Enterprises. Li (2016) conducted a research on working capital management and its effect on the profitability of Chinese listed firms. The researcher analyzed data, using both descriptive statistical analysis and regression analysis. The researchers concluded that efficient working capital management increases financial performance.

The purpose of the study was to show the main factors that impact working capital practices of some listed firms in China across the different industries and their effect on the firm's performance. The findings revealed that, Chinese listed firm's working capital policy is different across industries and stable over the research period. The researcher concluded that firms in China are prone to choose conservative working capital policy, which was shown to be positively associated to the firm's profitability. Madugba \& Ogbonnaya (2016) conducted a study on working capital management and financial performance: Evidence from manufacturing companies in Nigeria. These researchers used multiple regression analysis to analyze data sourced from published financial statement of the firms under study. The findings of the study revealed that, average payable period and average collection period have effect on the earnings per share (EPS) of manufacturing companies. Therefore, it was concluded in the study that working capital management have effect on financial performance of manufacturing companies in Nigeria. Ajayi, Abogun \& Odediran (2017), conducted a study on the effect of working capital management on financial performance of quoted consumer goods manufacturing firms in Nigeria. Secondary data were used, which was obtained from annual financial statements. Descriptive statistics was used to measure variations, while data was analyzed using correlation and panel regression analysis. The result revealed that, there exist a negative relationship between cash conversion cycle and financial performance while there a positive relationship between average collection period and financial performance. The researchers concluded that efficient working capital management increases financial performance. 


\section{Research Method}

Model Specification: The model used in this study specified return on capital employed (ROCE) as a function of average collection period (ACP), and average payment period (APP), alongside control variables including firm's size (FZ) and asset tangibility (ATANG). The model for the study is specified in function and linear forms below:

Functional and linear forms below:

ROCE $=f(A C P, A P P, F Z$, ATANG)

Linear representation of the models:

$R O C E_{i t}=\delta_{0}+\delta_{1} A C P_{i t}+\delta_{2} A P P_{i t}+\delta_{3} F Z_{i t}+\delta_{4} A T A N G_{i t}+\mu_{i t}----(3.1)$

Scope and Source of Data

This study sample twenty (20) manufacturing companies in Nigeria cutting across consumer goods subsector, and industrial goods sub-sector in Nigeria. Sampled industrial goods firms included Cutix Plc, Meyer Plc, Lafarge Africa plc, Berger Paints Plc, First Aluminium Nigeria Plc, Postland Paints and Products Nigeria Plc, Beta Glass Plc, Premier Paints Plc, Paints and Coatings Manufactures Plc, and Dangote Cement Plc, while sampled consumer goods firms included Unilever Nigeria Plc, PZ Cussons Nigeria Plc, Guinness Nigeria Plc, Nigerian Breweries Plc, Dangote Sugar refinery Plc, Nascon Allied Industries Plc, Dangote Flour Mills Plc, Flour Mills Nigeria Plc, Nestle Nigeria Plc, Vitafoam Nigeria Plc. The study employed static panel data analyses and pooled OLS estimator (fixed effect estimator, and random effect estimator), alongside post-estimation tests such as restricted f-test, Hausman test.

Analytical Framework: Samples used in this study were selected, using random sampling technique to establish the study area. The model used in this study showed that, the independent variables can cause a change (effect) in the dependent variables and the model was designed to test the significance of the population variance and as well as to evaluate the relationship among variables, with significance of beta value at $5 \%$ was interpreted using the probability values (P-value).

\section{Data Analysis and Results}

\section{Pooled OLS Estimation}

Table 1: Pooled OLS Estimation for Industrial and Consumer Goods Sub-Sectors Series: ROCE ACP APP FZ ATANG

\begin{tabular}{|c|c|c|c|c|c|}
\hline \multicolumn{3}{|c|}{ ESTIMATION FOR INDUSTRIAL GOODS } & \multicolumn{3}{|c|}{ ESTIMATION FOR CONSUMER GOODS } \\
\hline \multicolumn{2}{|c|}{ ROCE } & \multirow[b]{2}{*}{$\begin{array}{l}\text { Probability } \\
\text { (P-value) }\end{array}$} & \multicolumn{3}{|c|}{ ROCE } \\
\hline Variables & Coefficients & & Variables & Coefficients & $\begin{array}{l}\text { Probability } \\
\text { (P-value) }\end{array}$ \\
\hline $\mathrm{C}$ & 118.713 & 0.000 & $\mathrm{C}$ & 114.6776 & 0.000 \\
\hline ACP & -.0740812 & 0.178 & ACP & .014213 & 0.746 \\
\hline APP & -.0224144 & 0.516 & APP & -.0130166 & 0.528 \\
\hline FZ & -4.785711 & 0.000 & $\mathrm{FZ}$ & -5.299746 & 0.002 \\
\hline \multirow[t]{5}{*}{ ATANG } & -1.459307 & 0.916 & ATANG & 28.02316 & 0.008 \\
\hline & \multicolumn{2}{|c|}{ R-squared $=0.5590$} & \multicolumn{3}{|c|}{ R-squared= 0.6342} \\
\hline & \multicolumn{2}{|c|}{ Adjusted R-Squared=0.5236 } & \multicolumn{3}{|c|}{ Adjusted R-Squared $=0.5978$} \\
\hline & \multicolumn{2}{|c|}{ F-Statistics $=4.49$} & \multicolumn{3}{|c|}{ F-Statistics $=3.68$} \\
\hline & \multicolumn{2}{|c|}{ Probability $($ F-Statistics $)=0.0023$} & Probability & tistics) $=0.007$ & \\
\hline
\end{tabular}

Source: Authors Computation (2019)

Estimation results presented in table 1 revealed that both average collection period and average payment period exert negative effect on return on capital employed of industrial goods firms sampled in the study, with coefficient estimation of -0.0740812 ( $\mathrm{P}$-value $=0.178>0.05)$, and $-0.0224144(\mathrm{p}=0.516>0.05)$. For consumer goods firms, while average collection period exerts insignificant positive effect on return on capital employed with coefficient estimation of 0.014213 (P-value $=0.746>0.05$ ), average payment period exerts insignificant negative impact on return on capital employed with coefficient estimation of -0.0130166 (P- 
value $=0.528>0.05$ ). Reported R-squared stood at 0.5590 and 0.6342 for industrial goods and consumer goods respectively.

Table 2: Fixed Effect Estimation for Industrial and Consumer Goods Sub-Sectors Series: ROCE ACP APP FZ ATANG

\begin{tabular}{|c|c|c|c|c|c|}
\hline \multicolumn{3}{|c|}{ ESTIMATION FOR INDUSTRIAL GOODS } & \multicolumn{3}{|c|}{ ESTIMATION FOR CONSUMER GOODS } \\
\hline \multicolumn{2}{|c|}{ ROCE } & \multirow[b]{2}{*}{$\begin{array}{l}\text { Probability } \\
\text { (P-value) }\end{array}$} & \multirow{2}{*}{ Variables } & \multicolumn{2}{|c|}{ ROCE } \\
\hline Variables & Coefficients & & & Coefficients & $\begin{array}{l}\text { Probability } \\
\text { (P-value) }\end{array}$ \\
\hline $\mathrm{C}$ & 132.8605 & 0.072 & $\mathrm{C}$ & 186.2147 & 0.000 \\
\hline ACP & .019889 & 0.666 & ACP & -.0046292 & 0.890 \\
\hline APP & .0218892 & 0.374 & APP & -.0008444 & 0.961 \\
\hline $\mathrm{FZ}$ & -7.480904 & 0.134 & $\mathrm{FZ}$ & -6.549103 & 0.001 \\
\hline ATANG & 13.25505 & 0.466 & ATANG & -29.9852 & 0.009 \\
\hline \multicolumn{3}{|c|}{ Cross-Sectional Effects } & \multicolumn{3}{|l|}{$\begin{array}{l}\text { Cross- } \\
\text { Sectional } \\
\text { Effects }\end{array}$} \\
\hline MEYER & 48.06133 & 0.000 & PZ CUSSONS & -46.39357 & 0.000 \\
\hline WAPCO & 11.17615 & 0.701 & GUINNESS & -6.495728 & 0.252 \\
\hline BERGER & 25.96821 & 0.008 & NIGBREW & -4.226315 & 0.496 \\
\hline FIRSTALUM & -21.45898 & 0.140 & DANGSUGAR & -24.58557 & 0.000 \\
\hline PORTPAINT & 40.61835 & 0.000 & NASCON & -18.02632 & 0.019 \\
\hline BETAGLAS & -4.110097 & 0.816 & DANGFLOUR & -34.37387 & 0.000 \\
\hline PREMPAINT & -22.77673 & 0.039 & FLOURMILLS & -39.23654 & 0.000 \\
\hline PAINTCOM & -10.42224 & 0.231 & NESTLE & -2.846786 & 0.584 \\
\hline \multirow[t]{5}{*}{ DANGCEM } & 34.21057 & 0.317 & VITAFOAM & -40.08782 & 0.000 \\
\hline & \multirow{2}{*}{\multicolumn{2}{|c|}{$\begin{array}{l}\text { R-squared }=0.7496 \\
\text { Adjusted R-squared }=0.7118\end{array}$}} & \multicolumn{3}{|c|}{ R-squared=0.6455 } \\
\hline & & & Adjusted R-sq & $e d=0.5920$ & \\
\hline & \multicolumn{2}{|c|}{ F-statistics $=19.80$} & \multicolumn{3}{|c|}{ F-statistics $=12.05$} \\
\hline & \multicolumn{2}{|c|}{ Probability $(\mathrm{F}$-statistics $)=0.0000$} & \multicolumn{3}{|c|}{ Probability $(\mathrm{F}$-statistics $)=0.0000$} \\
\hline
\end{tabular}

Source: Authors Computation (2019)

Estimation results presented in table 2 revealed that both average collection period and average payment period, exert insignificant positive effect on return on capital employed of industrial goods manufacturing firms, with coefficient estimation of .019889 ( $\mathrm{P}$-value $=0.666>0.05)$ and -0.0218892 ( $\mathrm{P}$-value $=0.374>0.05$ ) respectively. On the other hand, estimation result for consumer goods sub-sectors revealed that both average collection period and average payment period exert insignificant negative effect on capital employed, with coefficient estimation of -0.0046292 (P-value $=0.890>0.05),-0.0008444$ (P-value $=0.961>0.05$ ) respectively.

Table 3: Random Effect Estimation for Industrial and Consumer Goods Sub-Sector Series: ROCE ACP APP FZ ATANG

\begin{tabular}{|c|c|c|c|c|c|}
\hline \multicolumn{3}{|c|}{ ESTIMATION FOR INDUSTRIAL GOODS } & \multicolumn{3}{|c|}{ ESTIMATION FOR CONSUMER GOODS } \\
\hline \multicolumn{2}{|c|}{ ROCE } & \multirow[b]{2}{*}{$\begin{array}{l}\text { Probability } \\
\text { (P-value) }\end{array}$} & \multicolumn{2}{|c|}{ ROCE } & \multirow[b]{2}{*}{$\begin{array}{l}\text { Probability } \\
\text { (P-value) }\end{array}$} \\
\hline Variables & Coefficients & & Variables & Coefficients & \\
\hline $\mathrm{C}$ & 118.0787 & 0.025 & $\mathrm{C}$ & 120.2984 & 0.000 \\
\hline ACP & .0134621 & 0.762 & ACP & -.017534 & 0.622 \\
\hline APP & .0191908 & 0.419 & APP & -.0080715 & 0.654 \\
\hline FZ & -5.906343 & 0.058 & $\mathrm{FZ}$ & -4.633044 & 0.009 \\
\hline \multirow[t]{4}{*}{ ATANG } & 15.00001 & 0.334 & ATANG & -5.357673 & 0.606 \\
\hline & 248 & & R-squared & & \\
\hline & $=17.10$ & & Wald chi2 & & \\
\hline & $\operatorname{chi} 2=0.0018$ & & Probabilit & $=0.0434$ & \\
\hline
\end{tabular}

Source: Authors Computation (2019) 
Estimation results presented in table 3 revealed that both average collection period and average payment period exert insignificant positive effect on return on capital employed of industrial goods manufacturing firms, with coefficient estimation of 0.0134621 ( $\mathrm{P}$-value $=0.762>0.05$ ) and 0.0191908 (P-value $=0.419>0.05$ ) respectively. On the other hand, estimation result for consumer goods sub-sector revealed that both average collection period and average payment period exert insignificant negative effect on return on capital employed, with coefficient estimation of -0.017534 (P-value $=0.622>0.05)$ and -0.0080715 (P-value $=0.654$ $>0.05$ ) respectively.

\section{Post Estimation Test}

Table 4: Restricted F Test of Heterogeneity (Cross-Sectional and Time Specific)

\begin{tabular}{lll}
\hline & F-Statistics & Probability \\
\hline Consumer Goods & 13.78 & 0.0000 \\
Industrial Goods & 22.54 & 0.0000 \\
\hline
\end{tabular}

Source: Authors Computation, (2019)

Table 5: Hausman Test

\begin{tabular}{llc}
\hline & Chi-Square Stat & Probability \\
\hline Consumer Goods & 2.13 & 0.7118 \\
Industrial Goods & 0.58 & 0.9655 \\
\hline
\end{tabular}

Source: Authors Computation, (2019)

Post-estimation test result presented in table 4 revealed that incorporating fixed effect into the intercept term of the model to track firm's heterogeneity effect among sampled firms is justified for both industrial goods and consumer goods sub-sector, with estimation statistics of 13.78 (P-value $=0.0000<0.05$ ) and 22.54 (Pvalue $=0.0000<0.05$ ) respectively. In the same vein Hausman test result presented in table 5 revealed that, there is no enough evidence to reject the null hypothesis that difference between fixed effect and random estimation result is not significant for industrial goods and consumer goods sub-sector. Hence, the most consistent and efficient estimation for both industrial goods and consumer goods sub-sector is the random estimation as contained in table 3 .

Table 6: Independent T-Test of Coefficient Estimates for Industrial and Consumer Goods Sub-Sectors WORKDING CAPITAL MANAGEMENT AND RETURN ON CAPITAL EMPLOYED

\begin{tabular}{llllll} 
Subsectors & Mean & $\begin{array}{l}\text { T-test } \\
\text { calculated }\end{array}$ & DF & Probability & Remark \\
\hline Industrial goods & 0.0163 & 5.267 & 2 & $0.034<0.05$ & Reject $\mathrm{H}_{0}$ \\
Consumer goods & -0.0128 & & & & \\
\hline
\end{tabular}

Source: Authors Computation (2019)

Independent t-test statistics presented in table 6 for working capital management and return on capital employed revealed that there is enough evidence to reject the null hypothesis that there is no significant difference between the effects exerted by working capital management variables on firms performance measured in terms of return on capital employed, hence the test result established that there is significant difference between the effect of working capital management on performance of industrial good firms and consumer good firms, when performance is measured by return on capital employed.

Discussion: Test results presented in tables 4, 5 and 6 revealed that, there is significant difference between the effect of working capital management on performance of industrial good firms and consumer good firms when performance is measured by return on capital employed. Specifically both average collection period and average payment period exert insignificant positive effect on return on capital employed of industrial goods manufacturing goods firms, with reported coefficient estimation of 0.0134621 (P-value $=0.762>0.05$ ) and $0.0191908(\mathrm{P}$-value $=0.419>0.05)$ respectively, while both average collection period and average payment period exert insignificant negative effect on return on capital employed of consumer goods industrial, with reported coefficient estimation of $-0.017534(\mathrm{P}$-value $=0.622>0.05)$ and $-0.0080715(\mathrm{P}$ - 
value $=0.654>0.05$ ) respectively. Observably, discoveries made in this study are equivalent with the findings of previous researches such as Naeem, Malik, Muhammed and Mehbood (2014), Akindele and Odusina (2015), Madugba and Ogbonnaya (2016).

\section{Conclusion and Recommendations}

The study established that there is significant difference between the effect of working capital management on performance of industrial good firms and consumer good firms when performance is measured by return on capital employed. Hence, firms in both industrial goods sub-sector and consumer goods sub-sector of the manufacturing sector in Nigeria should be strategic in harnessing the capacity of average payables period to manage working capital, so as to ensure that setting higher average payables period to better position working capital for improved firm's performance does not crowd-out their credit worthiness.

\section{References}

Adebayo, D. (2016). Nigeria's consumer goods sector: A diamond in the rough. Retrieved from www.dexteranalitics.com (22 $2^{\text {nd }}$ March, 2018).

Afza, T. \& Nazir, M. S. (2007). Is it better to be aggressive or conservative in managing working capital? Journal of quality and technology management, 3(2), 11-21.

Ahmadabadi, M. R., Mehrabi, E. \& Yazdi, A. F. (2013). Impact of working capital management on the performance of the firms listed on Tehran stock exchange, International journal of academic research in accounting finance and management science, 3(3), 352-364.

Ajayi, M. A., Abogun, S. \& Odediran, T. H. (2017). Impact of working capital management on financial performance of quoted manufacturing firms in Nigeria, Covenant journal of business and social sciences, $8(2), 1-22$.

Aluko, N. (2018). Nigerian industrial and consumer goods: overview and opportunities. Retrieved from www.kpakpakpa.com (22 $2^{\text {nd }}$ March, 2018).

Akindele, J. A. \& Odusina, A. 0. (2015). Working capital management and firm profitability: Evidence from Nigeria quoted companies, Research journal of finance and accounting, 6(7), 148-153.

Aminu, Y. \& Zainudin, N. (2015). A review of anatomy of working capital management theories and the relevant linkages for working capital components: A theoretical building approach, European journal of business and management, 7(2), 10-18.

Angahar, P. A. \& Alematu, A. (2014). Impact of working capital on the profitability of Nigerian cement industry, European journal of accounting, auditing and finance research, 2(7), 17-30.

Brealey, R. A., Myers, S. C. \& Allen, F. (2006). Account receivables management, Corporate Finance, (8 $8^{\text {th }}$ ed., 1520). New York: McGraw Hill/Irwin.

Brigham, E. F. \& Ehrhardt, M. C. (2004). Working capital management, financial management theory and practice, (11 th ed., Part 7). Ohio, Nigeria: Elm hill publisher.

Caballero, S. B., Teruel, P. J. G. \& Salano, P. M. (2014). Working capital management, corporate performance and financial constraints in United Kingdom, Journal of business research, 67, 332-338.

Central bank of Nigeria economy report. (2000). 61-95.

Central bank of Nigeria PMI report. (2017). 34-105.

Charitou, M., Lois, P. \& Christoforou, A. (2016). The relationship between aggressive and conservative working capital management policies and profitability, International journal of arts and commerce, 5(5), 143-150.

Cheng, N. S. \& Pike, R. (2003). The trade credit decision: evidence of UK firms, Journal of managerial and decision economics, 24(7), 419-438.

Chete, L. N., Adeoti, J. O., Adeyinka, F. M. \& Ogundele, O. (2016). Industrial development and growth in Nigeria: Lesson and challenges, 8, 1-38.

Chittenden, F., Poutziouris, P. \& Micheal, N. (1998). Financial Management and Working Capital Practices in UK SMEs, Manchester business school, Manchester.

Deloof, M. (2003). Does working capital management affect profitability of Belgian firms, Journal of business finance and accounting, 30, 573-587.

Duru, A. N. \& Okpe, I. I. (2016). Management of accounts payable on the financial performance of industrial, domestic manufacturing companies in Nigeria, Journal of humanities and social science, 21(7), 54-61. 
Elejelly, A. (2004). Liquidity-profitability tradeoff, International Journal of Commerce and Management, 14(2), 48-61.

Eya, C. I. (2016). Effect of working capital management on the performance of food and beverage industries in Nigeria, Arabian journal of business and management review, 6(5), 1-7.

Gill, A., Biger, N. \& Mathur, N. (2010). The relationship between working capital management and profitability: Evidence from the United States, Business and economics journal, 10, 1-9.

Gitman, L. J. (2009). Account receivable management, Principles of managerial finance, $\left(13^{\text {th }}\right.$ edition, 256309). Australia: Pearson prentice hall publisher

Haruna, A. M. (2016). Effects of working capital management on the performance of small and medium enterprises in Nigeria. Doctorate's thesis submitted to Jomo Kenyatta University of agriculture and technology Juja, Kenya.

Howorth, C. \& Westhead, P. (2003). The focus of working capital management in UK small firms, Management Accounting Research, 14, 26-35.

Iswatia, S. (2007). The influence of intellectual capital to financial performance at insurance companies Jakarta stock exchange, Melbourne, Australia: Proceedings of the $13^{\text {th }}$ Asia Pacific management conference, Melbourne, Australia.

Jagongo, A. O. \& Makori, D. M. (2013). Working capital management and firm profitability: Empirical evidence from manufacturing and construction firm listed on Nairobi securities exchange Kenya, International journal of accounting and taxation, 1(1), 1-14.

Jegede, M. (2017). Ajaokuta steel and Nigeria's industrialization dream, Retrieved July 11, 2018, from www.independentnews.ng

Knauer, T. \& Wohrman, A. (2013). Working capital management and firm profitability, Journal of management control, 24(1), 77-87

Lamberson, M. (1995). Changes in working capital of small firms in relation to changes in economic activity, Mid-American journal of business, 10(2), 45-50.

$\mathrm{Li}, \mathrm{Q}$. (2016). Working capital management and its effect on the profitability of Chinese listed firms. Master's thesis submitted to ISCTE business school, China.

Madugba, J. U. \& Ogbonnaya, A. K. (2016). Working capital management and financial performance: Evidence from manufacturing companies in Nigeria, European journal of accounting, auditing and finance research, 4(9), 98-106.

Mathur, B. S. (2003). Working capital policy, Working capital management and control principles and practice, (2nd revised ed., 9-29). New Delhi, India: New age international (P) limited, publisher.

Moles, P., Parrino, R. \& Kidwell, D. S. (2011). Working capital management and financial decisions, corporate finance, (European ed., Part 5). UK: John Wiley \&Sons, Ltd.

Mun, S. G. \& Jang, S. S. (2015). Working capital, cash holding and profitability of restaurant firms, International journal of hospitality management, 48, 1-11.

Naeem, U. H., Malik, M. I., Muhammad, A. \& Mehbood, H. (2014). Working capital management on firm performance: An empirical study of non-financial listed firms in Pakistan, International journal of academic research in business and social sciences, 4(6), 114-132.

Niresh, J. A. (2012). Working capital management and financial performance of manufacturing sector in Sri Lanka, European journal of business and management, 4(5), 1905-2222.

Ogundipe, S. E., Idowu, A. \& Ogundipe, L. D. (2012). Working capital management, firm's performance and market valuation in Nigeria, International journal of social, behavioral, educational, economics and industrial engineering, 6(1), 19-23.

Ojeani, N. R. (2014). Working capital management and profitability of listed pharmaceutical firms in Nigeria. Master's thesis submitted to Ahmadu Bello University Zaria, Nigeria.

Oladunjoye, P. (2011). Ajaokuta steel company another white elephant project, Retrieved July 112018. www.dailyindependentonline.ng

Osundina, J. A. (2014). Working capital management and profitability: Evidence from quoted food and beverages Manufacturing firms in Nigeria, Journal of finance and accounting, 5(4), 101-107.

Padachi, K. (2006). Trends in working capital management and its impact on firm's performance: An analysis of Mauritian small manufacturing firms, International review of business research papers, 2(2), 45-58.

Raheeman, A. \& Nasr, M. (2007). Working capital management and profitability, International review of business research papers, 3, 279-300. 
Salman, A. Y., Oyetayo O. F. \& Oriowo, A. O. (2014). Working capital management: A study of selected listed manufacturing companies in Nigerian stock exchange, International journal of academic research in business and social sciences, 4(8), 287-295.

Schwartz, R. A. (1994). An economic model of trade credit, Journal of financial and quantitative analysis, 9(4), 643-654.

Shim, J. K. \& Siegel, J. G. (2000). Financial management ( $2^{\text {nd }}$ ed.). Hauppauge, New York: Beuron Business Library.

Singh, J. P. (2004). Inventory and working capital management: An empirical analysis, The Kafia university journal of accounting research, 35, 1-72.

Uyar, A. (2009). The relationship of cash conversion cycle with firm size and profitability: An empirical investigation in Turkey, International research journal of finance and economics, 24, 186-193.

Vahid, T. k., Ealham, G., Moshsen, A. k. \& Mohammmadreza, E. (2012). Working capital management and corporate performance: Evidence from Iranian companies, Social and behavioral sciences, 62, 13131318.

Van Hore, J. C. (2001). Liability management and short/medium-term financing, financial management and policy, (12 ${ }^{\text {th }}$ ed., 483-518). New Jersey, United States: Prentice hall, upper saddle river.

Van Hore, J. C. \& Wachowicz, J. M. (2004). Overview of working capital management, Fundamentals of financial management, (12 ${ }^{\text {th }}$ ed., 304-480). New York, United States: Prentice Hall. 